\title{
A Comparative Study On Learning Outcomes Of Web Based Vs. Classroom Based Instruction
}

Zafer Unal, (zuu2343@fsu.edu), Florida State University

\begin{abstract}
This study investigates and compares the learning outcomes and student satisfaction of classroom versus web based instruction of the EDE4341 - Technology and Learning in Elementary and Middle Schools offered to preservice teachers in the Elementary Education program at Florida State University during Spring \& Summer 2004 semesters. While 20 students enrolled spring 2004 section which was taught face to face, 22 students enrolled Summer 2004 section which was taught online by the same instructor.
\end{abstract}

\section{INTRODUCTION}

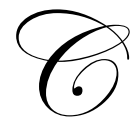

ountless evaluative literature has pointed to the conclusion that there is "no significant difference" between the face-to-face and the various models of distance learning, especially Internet based distance education (Russell 2000, Wegner at al., 1999). Examination of test scores and satisfaction survey results from the participants are used as evidence for most of these studies. Nevertheless, there exists the other face of the fact that some authorities still maintain that traditional classroom instruction is never equal to online education (Phipps \& Merisotis, 1999). One critic even branded virtual schools as "digital diploma mills" (Noble 1997). There is thus a perceptible need to confirm or disconfirm the claims of both camps regarding comparable effectiveness between traditional teaching and online teaching.

This study investigates and compares the learning outcomes and student satisfaction of classroom versus web based instruction of the EDE4341 - Technology and Learning in Elementary and Middle Schools offered to preservice teachers in the Elementary Education program at Florida State University during Spring \& Summer 2004 semesters. While 20 students enrolled spring 2004 section which was taught face to face, 22 students enrolled summer 2004 section which was taught online by the same instructor.

\section{HYPOTHESIS}

Web-based (distance education) instruction of EDE4341 (Technology and Learning in Elementary and Middle Schools) provided to Elementary Education pre-service teachers at FSU- Panama City Campus during Spring 2004 and Summer 2004 semesters will bring about the educational learning outcomes and course satisfaction comparable to that of face-to-face instruction.

\section{RESEARCH QUESTIONS}

- What effect does being instructed in a web-based learning environment have on pre-service elementary teachers' learning outcomes in comparison with that of being instructed in a face-to-face learning environment? 
- What effect does being instructed in a web-based learning environment have on pre-service elementary teachers' course satisfaction in comparison with that of being instructed in a face-to-face learning environment?

\section{METHODOLOGY}

A quasi-experimental pretest- posttest design with a control group employed to the study.

$$
\begin{aligned}
& \mathrm{N}_{1} \rightarrow \mathrm{O}_{1} \rightarrow \mathrm{O}_{2} \rightarrow \quad \mathrm{X}_{1} \rightarrow \quad \mathrm{O}_{3} \rightarrow \quad \mathrm{O}_{4} \rightarrow \quad \mathrm{O}_{5} \rightarrow \mathrm{O}_{6} \\
& \mathrm{~N}_{2} \rightarrow \mathrm{O}_{1} \rightarrow \mathrm{O}_{2} \rightarrow \quad \mathrm{X}_{2} \rightarrow \mathrm{O}_{3} \rightarrow \mathrm{O}_{4} \rightarrow \mathrm{O}_{5} \rightarrow \mathrm{O}_{6}
\end{aligned}
$$

$\mathrm{N}_{1}$-Pre-service elementary education teachers at FSU who will be instructed EDE4341 in a face-to-face classroom environment. (Control Group)

$\mathrm{N}_{2}$-Pre-service elementary education teachers at FSU who will be instructed EDE4341 in a web-based environment. (Experiment Group)

$\mathrm{O}_{1}$ - Online Readiness \& Learning Style Survey

$\mathrm{O}_{2}$ - Pretest: A computer literacy test

$\mathrm{X}_{1}$ - Face-to-face instruction of EDE4341

$\mathrm{X}_{2}-$ Web based instruction of EDE4341

$\mathrm{O}_{3}$ - Final exam that is a cumulative assessment of students learning in EDE4341

$\mathrm{O}_{4}-$ FSU Teaching Evaluation Form (SPOT)

$\mathrm{O}_{5}$ - A Focus group with randomly selected groups of students from both experimental and control groups.

$\mathrm{O}_{6}-$ Student portfolios.

\section{DATA COLLECTION}

Both quantitative and qualitative methods used to collect data for the study.

Quantitative data collected using the following instruments:

- $\quad$ Online Readiness \& Learning Style Survey

- $\quad$ Computer Literacy Test (Pre-test),

- $\quad$ Final exam (Post-test),

- $\quad$ FSU Teaching Evaluation Form (SPOT) (course satisfaction),

- $\quad$ Student Portfolios and

- $\quad$ Student Grades

Qualitative data collected using a

- $\quad$ Focus group with randomly selected students from both experiment and control groups. See below for more information and appendix for samples of instruments.

\section{DATA ANALYSIS}

At the beginning of each class sessions, a 96 item survey was given the students to collect demographic information and to investigate students' learning style and online readiness. The findings from the survey as follows:

\section{Demographic Information}

\begin{tabular}{|l|c|c|c|c|l|}
\hline Method & Enrolled & Gender & Age & GPA & Learning Style \\
\hline Classroom & 20 & $20 \mathrm{~F}$ & 26.75 & 3.71 & Participant-Collaborative-Dependent \\
\hline Online & 22 & $22 \mathrm{~F}$ & 28.77 & 3.58 & Participant-Collaborative-Dependent-Independent \\
\hline
\end{tabular}




\section{Online Readiness}

All of the students $(100 \%)$ enrolled to this study had at least one computer with Internet connection at home. Also online readiness survey showed that both groups had the required computer knowledge and skills to take an online course.

\section{Comparing Pretest Scores}

The pre-test exam was given to students from both classroom and online sections to determine students' previous knowledge on the course content.

\begin{tabular}{|c|c|c|c|c|c|}
\hline \multicolumn{2}{|l|}{ Method } & \multicolumn{4}{|l|}{ Pre-test Scores } \\
\hline \multicolumn{2}{|l|}{ Classroom Based } & \multicolumn{4}{|c|}{$25,31,32,33,34,36,37,37,38,43,44,44,44,46,47,48,49,49,51,55$} \\
\hline Online Based & & \multicolumn{4}{|c|}{$31,34,35,35,36,37,37,38,38,38,39,39,39,39,40,42,43,44,44,47,52,52$} \\
\hline \multicolumn{6}{|c|}{ Student's t test for independent samples / two-tailed test } \\
\hline Sample & Sample size & Mean & Variance & SD & Standard-error \\
\hline Classroom & 20 & 41.150 & 62.134 & 7.883 & 1.763 \\
\hline Online & 22 & 39.955 & 28.522 & 5.341 & 1.139 \\
\hline
\end{tabular}

Using XSLAT, the following comparison results achieved. Decision: At the level of significance Alpha $=0.050$ the decision is to not reject the null hypothesis that (Mean1 - Mean2) is equal to 0.005. In other words, the difference between (Mean1 - Mean2) and 0.005 is not significant.

\section{Comparing Post-Test Scores}

The pre-test exam was given to students from both classroom and online sections to determine students' previous knowledge on the course content.

\begin{tabular}{|c|c|c|c|c|c|}
\hline \multicolumn{2}{|l|}{ Method } & \multicolumn{4}{|l|}{ Post-test Scores } \\
\hline \multicolumn{2}{|l|}{ Classroom Based } & \multicolumn{4}{|c|}{$60,55,57,58,64,66,68,60,58,64,70,68,68,70,61,70,71,69,72,70$} \\
\hline \multicolumn{2}{|l|}{ Online Based } & \multicolumn{4}{|c|}{$58,50,54,56,61,59,55,60,59,60,59,67,68,66,68,65,68,70,65,70,71,72$} \\
\hline \multicolumn{6}{|c|}{ Student's t test for independent samples / two-tailed test. } \\
\hline Sample & Sample size & \begin{tabular}{|l|l|} 
& Mean \\
\end{tabular} & Variance & SD & Standard-error \\
\hline Classroom & 20 & 64.950 & 29.481 & 5.424 & 1.231 \\
\hline Online & 22 & 62.773 & 38.470 & 6.202 & 1.332 \\
\hline
\end{tabular}

Using XSLAT, the following comparison results achieved. Decision: At the level of significance Alpha $=0.050$ the decision is to not reject the null hypothesis that (Mean1 - Mean2) is equal to 0.005. In other words, the difference between (Mean1 - Mean2) and 0.005 is not significant.

\section{Comparing Pre-test \& Post-test Scores}

The pre and post-test data also indicates that the classroom based class showed $\% 56.09$ percent improvement while online based class showed $\% 58.97$ percent of improvement between pre and posttest scores at the end of each sessions. 


\section{Comparing Course Satisfaction (SPOT)}

The Student Perception of Teaching survey given students to measure preservice teachers' course satisfaction from both sessions. The survey includes 26 questions collecting students' feedback on Course \& Instructor Details, Overall Course \& Instructor Assessment, and SUSSAI (State University System Student Assessment of Instruction).

The answers to SPOT survey coded as follows,

1.00 to 1.49 Strong disagreement

1.50 to 2.49 Disagreement

2.50 to 3.49 Neutral

3.50 to 4.49 Agreement

4.50 to 5.00 Strong agreement
(Highly Negative)

(Negative)

(Neutral)

(Positive)

(Highly Positive)

\begin{tabular}{|l|c|c|c|c|}
\hline Method & $\begin{array}{c}\text { Course \& Instructor } \\
\text { Details }\end{array}$ & $\begin{array}{c}\text { Overall Course \& } \\
\text { Instructor Assessment }\end{array}$ & $\begin{array}{c}\text { SUSSAI (State University System } \\
\text { Student Assessment of Instruction) }\end{array}$ & $\begin{array}{c}\text { Overall } \\
\text { (Mean) }\end{array}$ \\
\hline Classroom & 4.83 & 4.85 & 4.86 & Mean1 $=4.847$ \\
\hline Online & 4.65 & 4.94 & 4.91 & Mean2 $=4.833$ \\
\hline
\end{tabular}

Using XSLAT, the following comparison results achieved. Decision: At the level of significance Alpha $=0.050$ the decision is to not reject the null hypothesis that (Mean1 - Mean2) is equal to 0.005. In other words, the difference between (Mean1 - Mean2) and 0.005 is not significant.

\section{Student Portfolio Evaluation}

Student portfolio was the main assignment of the course required for both classroom and online sessions. Each student had a portfolio which includes thirteen assignment completed at the end of the semester. The portfolio was graded using a rubric by both course instructor and a colleague to maintain objective results.

\begin{tabular}{|l|c|c|c|}
\hline \multicolumn{1}{|c|}{ Method } & Portfolio Completed & Portfolio Grade (Mean) & Overall Grade (Mean) \\
\hline Classroom & $100 \%$ & $97 \%$ & $98 \%$ \\
\hline Online & $100 \%$ & $94 \%$ & $96 \%$ \\
\hline
\end{tabular}

\section{Focus Group Interview}

At the end of both sessions, a focus group interview conducted by a colleague to collect data about the course and student satisfaction from the course with 6 randomly selected students from each session.

\section{CONCLUSION}

The study findings shows that online instruction of EDE4341 (Technology and Learning in Elementary and Middle Schools) provided to Elementary Education pre-service teachers at FSU- Panama City Campus during Spring 2004 and Summer 2004 semesters brought about the educational learning outcomes and course satisfaction comparable to that of face-to-face instruction. In other words, the findings of the study indicates that there is no significant difference between the learning outcomes (pre-test, post-test, student grades, portfolio) and student satisfaction (SPOT Survey) of the classroom and online version of the course. 
The most common statements form the focus group interviews as follows,

\begin{tabular}{|c|c|}
\hline Classroom Based & Online \\
\hline $\begin{array}{l}\text { - The course was a success } \\
\text { - Very satisfied from the course and instructor } \\
\text { - } \\
\text { - } \\
\text { - } \text { The course content was appropriate to their major and level } \\
\text { - } \quad \text { Posting materials online helps them to review } \\
\text { - Step by step instruction helps them learn effectively } \\
\text { - They enjoyed online projects especially WebQuest and } \\
\text { - Weblesson } \\
\text { If this course offered online, the students should be } \\
\text { informed before enrolling the course to make right } \\
\text { decision } \\
\text { Most of them would not take this course, if offered } \\
\text { online }\end{array}$ & $\begin{array}{l}\text { - The course was a success } \\
\text { - Very satisfied from the course, instructor and course } \\
\text { website } \\
\text { - They did not have any technical problem reaching the } \\
\text { course website } \\
\text { - Discussion board was the main tool for them to learn } \\
\text { - The layout of the course on the course website was very } \\
\text { useful and help them easily navigate } \\
\text { - Instructor answered questions promptly } \\
\text { - The course handbook was a big help and a must for the } \\
\text { - Course content was appropriate to their major and level }\end{array}$ \\
\hline
\end{tabular}

\section{REFERENCES}

1. Noble, D.F. (1997). "Digital diploma mills: The automation of higher education". First Monday Peer Reviewed Journal, 3(1), Retrieved on Sep 11, 2003, from www.firstmonday.dk/issues/ issue3_1/noble/index.htm

2. Phipps, R., \& Merisotis, J. (1999). "What's the difference? A review of contemporary research on the effectiveness of distance learning in higher education." Washington DC: Institute for Higher Education Policy, for the American Federation of Teachers \& National Education Association. Retrieved on September 12, 2003, from http://www.ihep.com/Pubs/PDF/Difference.pdf

3. Russell, T. L. (2000). "The no significant difference phenomenon." Raleigh: North Carolina State University.

4. Wegner, S. B., Holloway, K.C., \& Garton, E.M. (1999). "The effects of Internet-based instruction on student learning." Journal of Asynchronous Learning Networks, 3(2). Retrieved on September 10, 2003, from http://www.aln.org/alnweb/journal/jaln-vol3issue2.htm 
NOTES 